\title{
Pengambilan Keputusan Untuk Meningkatkan Kualitas Asuhan Keperawatan di Pusat Pelayanan Kesehatan
}

\author{
Sri Rezeki Silalahi \\ srisilalahi2604@gmail.com
}

\section{LATAR BELAKANG}

Pengambilan keputusan merupakan suatu pendekatan sistematis untuk menyelesaikan suatu masalah. Kemampuan membuat keputusan masalah etis menjadi salah satu persyaratan bagi perawat untuk menjalankan praktik keperawatan professional. Pengambilan keputusan yang tepat menggunakan suatu pendekatan yang sistematis terhadap hakekat suatu masalah dengan pengumpulan data data dan fakta. Pengambilan keputusan memilih pelayanan yang akan berdampak pada kepuasan dan ketidakpuasan setelah konsumen menggunakan pelayanan. Pelayanan kesehatan yang baik adalah pelayanan kesehatan yang dapat dijangkaui, mudah dicapai, tersedia di masyarakat dan berkesinambungan.

Perawat yang merupakan tenaga professional bertanggungjawab dalam memberikan proses keperawatan kepada klien. Berdasarkan hal tersebut perawat harus mampu mengambil keputusan dalam upaya membantu pasien dalam memecahkan masalah dan menemukan jalan keluar dari setiap masalah keperawatan yang dialami oleh pasien. Perawat selalu dihadapkan dengan berbagai masalah klinis dalam memberikan perawatan terhadap pasien. Perawat yang professional tentun saja akan mampu mengambil keputusan klinis agar masalah pasien dapat diatasi dengan cepat dan tepat. Kurangnya kemampuan perawat dalam mengambil keputusan dalam situasi kritis tentu saja akan membahayakan pasien dan menimbulkan kerugian bagi pasien, diantaranya pasien akan semakin memburuk dan akibat yang paling fatal adalah kematian (Potter\&Perry,2009). Kemampuan membuat keputusan oleh perawat merupakan inti dari praktik keperawatan. Kualitas suatu rumah sakit sudah tentu tergantung juga pada kualitas yang diberikan oleh perawat karena perawat merupakan jumlah tenaga kesehatan yang paling banyak di rumah sakit, perawat juga merupakan yang paling lama berinteraksi dengan pasien. Dalam pengamblan keputusan juga penting bagi perawat untuk mampu melakukan pengambilan keputusan klinis dengan melibatkan pasien dan keluarga dalam asuhan keperawatannya sehingga proses keperawatan yang diberikan pada klien diarahkan 
sebagai proses refleksi baik bagi perawat maupun klien. Oleh karena itu kualitas pelayanan keperawatan sangatlah pentingnya untuk diperhatikan oleh pihak rumah sakit.

\section{METODE}

Jurnal ini menggunakan metode literature review dari berbagai sumber seperti buku referensi jurnal dan juga membandingkan beberapa jurnal yang berhubungan dengan pengambilan keputusan untuk meningkatkan kualitas asuhan keperawatan di pusat pelayanan kesehatan. Dari analisi berbagai sumber yang digunakan untuk mengetahui pentingnya pengambilan keputusan untuk meningkatkan kulaitas asuhan keperawatan di pusat pelayanan kesehatan. Pengolahan jurnal dilakukan dengan metode membandingkan beberapa jurnal yang berkaitan dengan pengambilan keputusan untuk meningkatkan kualitas asuhan keperawatan di pusat asuhan keperawatan.

\section{HASIL}

Proses pengambilan keputusan klinis merupakan komponen penting dalam proses keperawatan sehingga dibutuhkan kemampuan perawatan. Keterbatasan pengetahuan dan kemampuan yang dimiliki perawat dapat menghambat perawat dalam mengambil keputusan mengenai perawatan yang akan diberikan kepada klien yang akan berakibat fatal terhadap klien. Pengambilan keputusan yang tepat menggunakan suatu pendekatan yang sistematis terhadap hakekat suatu masalah dengan pengumpulan fakta-fakta dan data. Dalam menentukan alternatif yang matang untuk mengambil suatu tindakan yang tepat didasarkan pada kriteria tertentu atas dua atau lebih alternatif yang sesuai. Pengambilan keputusan dalam penyelesaian masalah membutuhkan kemampuan yang mendasar bagi praktisi kesehatan, khususnya dalam asuhan keperawatan (Dolan, 2017). Pengambilan keputusan tidak hanya berpengaruh pada proses pengelolaan asuhan keperawatan, tetapi penting untuk meningkatkan kemampuan merencanakan perubahan. Perawat pada semua tingkatan posisi klinis harus memiliki kemampuan menyelesaikan masalah dan mengambil keputusan yang efektif, baik sebagai pelaksana/staf maupun sebagai pemimpin. Pengambilan keputusan sangat penting keberadaannya dalam asuhan maupun dalam manajemen keperawatan. Pengambilan keputusan merupakan suatu proses yang mencakup semua penilaian kegiatan yang diperlukan guna membuktikan dan meperlihatkan pilihan terbaik dalam menyelesaiakan suatu masalah tertentu. Setiap keputusan adalah akibat dari sebuah proses dinamis yang dipengaruhi oleh banyak kekuatan, pengambilan keputusan bukan merupakan prosedur yang tetap akan tetapi sebuah proses yang beruntun. pengambilan keputusan adalah proses yang 
melibatkan pendekatan sistemik yang harus diadaptasikan dengan lingkungan. Dalam pengambilan keputusan seorang perawat harus berlandaskan etika praktik keperawatan yang berdasarkan pada pemikiran kritis dan reflektif mengenai tanggung jawab dan kewajiban seorang perawat terhadap klien. Dalam pengambilan keputusan perlu kolaborasi perawat klien yang merupakan komponen utama dalam pemberian asuhan keperawatan, pengambilan keputusan merupakan bagian dari asuhan keperawatan, sehingga pengambilan keputusan dalam proses keperawatan harus melibatkan pasien dan keluarganya. Keterlibatan klien yang dimaksud dalam pengambilan keputusan ini adalah sebagai upaya pemberdayaan klien sehingga meningkatka tingkat kemandirian klien.

\section{PEMBAHASAN}

\section{Elemen Pengambilan Keputusan}

A. Pengumpulan Data

Pengumpulan data adalah suatu proses pendekatan kepada subjek dan proses pengumpulan karakteristik subjek yang diperlukan dalam suatu penelitian. Langkah langkah dalam pengumpulan data bergantung pada rancangan penelitian dan teknik instrument yang digunakan. Selama proses pengambilan data, peneliti memfokuskan pada penyediaan subjek, melatih tenaga pengumpul data, memperhatikan prinsipprinsip validitas dan rehabilitas serta menyelesaikan masalah-masalah yang terjadi agar data dapat terkumpul sesuai dengan rencana yang ditetapkan. Karakteristik Metode pengumpulan data terdiri dari beberapa dimensi yaitu:

1. Struktur. Pengumpulan data penelitian sering disusun berdasarkan struktur tertentu,yaitu pengumpulan data yang benar benar sesuai pada subjek

2. Kuantitatif. Data yang dikumpulkan pada penelitian kuantitatif harus disusun berdasarkan perhitungan sehingga dapat dianalisis secara statistic. Sebaliknya, data pada penelitian kualitatif dapat dianalisis secara kualitatif dan dikumpulkan berdasarkan format narasi

3. Obstrusiveness. Pengumpulan data harus berdasarkan pada kemampuan status subjek. Pengumpulan data yang diketahui oleh subjek biasanya cenderung memperoleh feedback yang tidak normal. Tetapi jika dilaksanakan tanpa pengetahuan subjek, maka akan berdampak terhadap masalah etika

4. Objektif. Pengumpulan data sebaiknya dilaksanakan secara objektif,sejauh mungkin menghindari unsur subjektivitas. Tetapi pada penelitian social,pengambilan keputusan secara subjektif lebih bermakna. 


\section{B. Hipotesa}

Hipotesa dapat dinyatakan dengan berbagai cerita, pernyataan hipotesis harus ditulis dalam bentuk jawaban pertanyaan yang diajukan studi. Hipotesis ini harus berisi hubungan yang diharapkan, harus dinyatakan dengan jelas dan ringkas, dan harus didasarkan pada teori yang dapat diterima dan/temuan rise yang valid jika memungkinkan. Selain itu hipotesa juga dapat diuji yaitu peneliti merupakan hipotesa studi riset yang kemudian di terima atau ditolak secara statistic. Keberhasilan suatu riset tidak bergantung pada hipotesis yang didukung data. Studi riset yang didesain dan dilakukan dengan baik yang hipotesanya ditolak juga dapat memverikan dasar pengetahuan yang sama banyaknya, dan pada teori asal nya seperti yang diberikan oleh studi yang didesain dan dilaksanakan dengan baik dengan hipotesa yang diterima.

C. Rencana Kegiatan

Rencana tindakan adalah desain spesifik intervensi untuk membantu komuniktas mencapai kriteria hasil. Rencana tindakan dilaksanakan berdasarkan komponen penyebab diagnose keperawatan. Oleh sebab itu, rencana mendefinisikan suatu aktifitas yang diperlukan untuk membatasi factor-faktor pendukung terhadap suatu permasalahan.

D. Pemecahan Masalah

Proses pemecahan masalah adalah penentuan praktis mengenai suatu cara pemecahan pada sebuah masalah. Masalah masalah yang timbul dalam praktik keperawatan sehari hari seringkali tidak dapat menunggu suatu penyelidikan riset untuk memberikan jawaban yang terbaik. Proses pemecahan masalah meliputi mengidentifikasi masalah, menetapkan semua pilihan yang tersedia untuk memecahkan masalah,melaksanakan alternative yang terbaik dan mengevaluasi keefektifan. Kebanyakan perawat telah menggunakan proses pemecahan masalah dalam usaha untuk menyelesaikan masalah perawatan pasien yang timbul, umumnya perawat harus menentukan tentang bagaimana bertindak dalam suatu situasi baru. Perawat biasanya memeriksa pengalaman masa lalu dengan masalah masalah yang serupa dan meramal kan kemungkinan fakta fakta yang sesuai untuk dapat diterapkan dalam situasi saat ini. Pengetahuan yang tidak dapat diperoleh dari pengalaman biasanya adalah pemecahan masalah. Contohnya seorang perawat kesehatan masyarakat melkaukan kunjungan rumah pada orang tua baru yang merupakan bagian 
dari program pemulangan awal dari rumah sakit local. Ketika mengunjungi salah satu kelarga baru, perawat menemukan keluarga telah memberikan jus/air jeruk pada bayinya yang baru lahir untuk membersihkan darah setelah melahirkan.Perhatian terhadap kesejahteraan bayi ini memerlukan perawat untuk menyelidiki cara pemecahan lain. Hal ini merupakan pemecahan masalah umtuk memenuhi maslaah segera

E. Asumsi

Sebuah asumsi adalah sebuah pernyataan yang kebenaran atau validitasnya diperhitungkan. Asumsi juga dapat dibuktikan sendiri karena tidak membutuhkan uji lebih lanjut. Asumsi didasarkan pada teori yang ditetapkan pada topic studi,atau dapat didasarkan pada temuan riset sebelumnya. Pada kebanyakan studi,asumsi disampaikan oleh peneliti dan perlu dinyatakan secara eksplisit. Jika asumsi tersebut cukup signifikan untuk mempengaruhi kelangsungan atau hasil studi, peneliti harus menyatakan secara eksplisit sehingga orang lain dapat mengevaluasi pengaruhnya pada studi.

\section{Tahap Pengambilan Keputusan}

Pengambilan keputusan sangat penting keberadaannya dalam asuhan maupun dalam manajegen keperawatan. Pengambilan keputusan merupakan suatu proses yang mencakup semua penilaian kegiatan yang diperlukan guna membuktikan dan memperlihatkan pilihan terbaik dalam menyelesaikan suatu masalah tertentu. Setiap keputusan adalah akibat dari sebauh proses dinamis yang dipengaruhi oleh banyak kekuatan, pengambilan keputusan bukan merupakan prosedur yang tetap akan tetapi sebuah proses yang beruntun, pengambilan keputusan adalah proses yang melibatkan pendekatan sistemik yang harus diadaptasikan dengan lingkungan.

Pengambilan keputusan keperawatan dilakukan pada semua tahap proses keperawatan sehingga seorang perawat harus mampu berpikir kritis, berkomunikasi dengan baik sebagai suatu elemen penting dalam pengambilan keputusan klinis, sehingga terjadi pembelajaran berkelanjutan bagi pasien sehingga meningkatkan tingkat kemandirian pasien. Defenisi lain dijelaskan pengambilan keputusan klinis keperawatan merupakan sernagkaian keputusan yang dibuat oleh perawat, dalam interaksi dengan klien mengenai pengkajian yang didapat dari klien, evaluasi data yang diamati, variasi diagnose yang muncul serta tindakan yang harus diambil. Proses dasar pembuatan keputusan mencakup identifikasi dan diagnosa masalah yaitu mengenali (mengidentifikasi) masalah, penumpulan data yang relevan yaitu 
menentukan data data yang akan dibutuhkan untuk membuat keputusan yang tepat dan kemudai mendapatkan informasi tersebut, pengembangan alternative yaitu pencarian solusi potensial untuk masalah tersebuat guna memperoleh informasi sehingga dapat dikembangkan menjadi alternative yang mungkin. Selanjutnya evaluasi alternative yaitu mengevaluasi untuk menilai efektivitas setiap alternatif dengan melihat dampak positif dan dampak negatifnya, pemilihan alternative terbaik yaitu memecahkan guna mencapai tujuan yang direncanakan yang sebelumnya. Selanjutnya implementasi keputusan yaitu menguji keputusan dengan melihat perilaku orang yang dipengaruhi keputusan itu serta pengendalian dan evaluasi yaitu perubahan dan solusi yang dipilih pada saat imlementasi atau jika tujuan awal dianggap belum tercapai.

\section{PENUTUP}

\section{Kesimpulan}

Pengambilan keputusan merupakan hal penting untuk diperhatikan oleh perawat berkaitan dengan kualitas pemberian asuhan keperawatan. Dan untuk mengambil suatu keputusan perawat tidak boleh asal-asalan dan harus memperharikan banyak hal yang nantinya menjadi keputusan yang terbaik.

\section{Saran}

a. Rumah sakit : Menggali metode untuk meningkatkan kemampuan berpikir kritis para perawat dalam mengambil keputusan dan penting bagi divisi keperawatan untuk menyusun rencana dan pelatihan yang mendukung untuk meningkatkan kemampuan berpikir kritis

b. Perawat : meningkatkan berpikir kritis dalam pengambilan keputusan yang dilakukan dengan diskusi kasus dan ronde keperawatan. 


\section{REFERENSI}

Brockopp Dorothy Young,Marie T Hasting-Tolsma. Dasar Dasar Riset Keperawatan. Jakarta:EGC

Dempsey,Patricia Ann.2002. Riser Keperawatan: Buku Ajar Dan Latihannya. Jakarta: EGC

DS Bambang Sudono, Dhani Setya, Ria Atiningtyas H. 2017. Gambaran Kemampuan Berpikir Kritis Perawat Primer dalam Pelaksanaan Asuhan Keperawatan di Rumah Sakit Islam Surakarta. Jurnal Ilmu Keperawatan Indonesia Vol 10(1)

https://jurnal.usahidsolo.ac.id/index.php/JIKI/article/download/188/148

Efendi Ferry, Mahfudli. 2009. Keperawatan Kesehatan Komunitas Teori dan Praktik dalam Keperawatan. Jakarta: Salemba Medika

Erianti Susi, Rizanda Machmud, Harmawati. 2019. Determinan Pengambilan Keputusan Klinik Keperawatan di RSUD Arifin Achmad Provinsi Riau. Jurnal Kesehatan Komunitas Vol 5(3).

http://jurnal.htp.ac.id

Khairina Ilfa , Hema Malini, Emil Huriani. 2018. Faktor Faktor Yang Berhubungan Dengan Pengambilan Keputusan Perawat Dalam Ketepatan Triase Di Kota Padang. Indonesian Journal for Health Sciences Vol 2(1)

http://journal.umpo.ac.id/index.php/IJHS/article/download/707/694

Mariana Dina. 2019. Hubungan Kualitas Pelayanan Keperawatan Rawat Inap Dengan Proses Pengambilan Keputusan Pasien Untuk Memilih Rumah Sakit. Jurnal Ilmiah Multi Science Kesehatan Vol 10(2)

http://jurnal.stikes-aisyiyah-palembang.ac.id/index.php/Kep/article/download/191/170

Nursalam.2008. Konsep Dan Penerapan Metodologi Penelitian Ilmu Keperawatan. Jakarta: Salemba Medika

Purwati Estik Ikka Indah, Nuryadi, Yennike Tri Herawati. 2017. Pengambilan Keputusan Dalam Pelaksanaan Rujukan Puskesmas Sebagai Fasilitas Kesehatan Tingkat Pertama. eJurnal Pustaka Kesehatan Vol 5(2). 
https://jurnal.unej.ac.id/index.php/JPK/article/download/5492/4117/

Rahayu Candra Dewi, Sri Mulyani. 2020. Pengambilan Keputusan Klinis Keperawatan. Jurnal Ilmiah Kesehatan Vol 10(1).

https://ojs.unsiq.ac.id/index.php/jik/article/view/1332/780

Simamora, R. H. (2019). Menjadi perawat yang: CIH'HUY. Surakarta: Kekata Publisher.

Simamora, R. H. (2005). Hubungan Persepsi Perawat Pelaksana Terhadap Penerapan Fungsi Pengorganisasian Yang Dilakukan Oleh Kepala Ruangan Dengan Kinerjanya Diruang Rawat Inap RSUD Koja Jakarta Utara (Doctoral dissertation, Tesis FIK UI, Tidak dipublikasikan). 